\title{
Ensino de história e a história pública: os testemunhos da Comissão Nacional da Verdade em sala de aula
}

History Teaching and Public History: The Testimonies of the National Truth Commission in the Classroom

Marta Gouveia de Oliveira Rovai*

\section{RESUMO}

$\mathrm{O}$ artigo discute o ensino de história com base no conceito de história pública como comprometimento com a produção, divulgação e compartilhamento de passados vivos, no sentido de construção da consciência histórica e compromisso com a democracia. Para que o professor possa orientar em sala de aula o acesso aos testemunhos públicos disponibilizados pela Comissão Nacional da Verdade (CNV) nas redes sociais, o artigo propõe reflexões e sugestões, a fim de que os alunos possam compreender as diferentes narrativas de vítimas e perpetradores de forma sistematizada e sob olhar histórico e ético. Desta forma, pretende-se contribuir para que discursos, principalmente os defendidos pelos agentes da repressão e que estão circulando sem ponderação histórica, sejam analisados como disputas de memória e poder, de forma a combater distorções, revisionismos e negacionismos sobre experiências sensíveis.

Palavras-chave: história pública; ensino de história; testemunhos públicos.

\section{Abstract}

This article proposes to think of the teaching of history, starting from the concept of public history as a commitment to the production, dissemination and sharing of living past, in the sense of constituting historical awareness and commitment to democracy. Suggestions and reflections are proposed on how, in the classroom, the teacher can guide access to public testimonies, made available by the Comissão Nacional da Verdade (CNV) on social networks, so that students can understand the different narratives of victims and perpetrators of systematized form and under historical and ethical perspective. In this way, it is intended to contribute to discourses, mainly defended by agents of repression and that are in circulation without historical consideration, to be analysed as disputes of memory and power in order to combat distortions, revisionism and negationism about sensitive experiences.

Keywords: Public History; History teaching; public testimony.

\footnotetext{
* Universidade Federal de Alfenas (Unifal/MG), Alfenas, MG, Brasil. martarovai88@mail.com
} 
A história pública não deveria ter medo de abraçar a controvérsia.

Gerald Zahavi

A concepção de história pública pode se basear em duas dimensões: uma delas preocupa-se com a difusão do conhecimento histórico, ampliando a audiência com a divulgação científica em diferentes espaços públicos fora da Academia; a outra surge como um conjunto de procedimentos que pode contribuir com modelos participativos de construção de saber e de intervenção objetiva em diferentes espaços públicos, incluindo a sala de aula. Segundo Ricardo Santhiago (2018, p. 288), o primeiro modo de entender a história pública - voltada à difusão histórica - vê como um "arremedo pragmatista" a realização de considerações sobre os usos do passado ou sobre a cultura histórica. O compromisso com reflexões e diagnósticos sobre o acontecido, em suas conexões com demandas do presente, não seriam seus objetivos, uma vez que não se considera pertinente a utilização da definição de história pública para um campo ou conjunto de práticas do historiador. A outra forma de concebê-la, entretanto, impõe ao pesquisador/professor múltiplos comprometimentos quanto à elaboração e/ou análise da produção, aos atos interpretativos e disponibilização pública, levando em conta as relações com o público, de forma a orientar visões de história que insiram as pessoas no tempo e as ajudem a projetar o futuro.

A segunda concepção aqui apresentada é a que embasa a reflexão e a proposta deste artigo, voltado aos usos de depoimentos públicos e sensíveis em sala de aula. Entendo que a escola é espaço coletivo de construção e de interpretações de conhecimentos que circulam por toda parte. Nela é possível realizar ponderações mais sistematizadas em torno de saberes difundidos fora dela; território de disputas em que se seleciona e se promove a publicização de determinados temas com objetivos de aprendizados específicos; e é, enfim, espaço de (re)elaboração e devolução coletiva de conhecimentos pelas experiências dos sujeitos envolvidos. Tudo isso requer do professor um compromisso muito grande nas várias atividades didáticas, no cuidado com o material que será utilizado como fonte de discussões e na divulgação do que foi compartilhado.

Quando usamos a expressão história pública, costumamos ouvir de muitos docentes que ela já se constitui como uma prática em sala de aula. Essa concepção parece ser uma associação natural, pois as aulas de história, de fato, se 
caracterizam por um tipo de apropriação dos eventos do passado e também por sua transmissão a uma assistência formada pelos discentes. O livro didático, os usos de mídias, a oralidade e o diálogo em sala de aula são formas de difusão de conhecimentos históricos, seja pela recriação de conteúdos, pela troca de experiências ou por eventos que atravessam a escola e colocam o professor muito além de mero reprodutor daquilo que foi chancelado pela Academia.

Ao ensinar, o profissional deve levar em conta os inúmeros meios de comunicação que contribuem para desenvolver formas de entender o passado e o presente entre as novas gerações. A produção de conhecimento histórico escolar não se restringe mais à universidade e ao material mais tradicional, como os livros didáticos, recursos pelos quais, em muitas oportunidades, é possível tornar público um conjunto de saberes. Como afirmam Everardo P. de Andrade e Nívea Andrade (Andrade; Andrade, 2017, p. 178), a ideia de que o professor seja aquele que transpõe a ciência pelo uso do livro didático em sala de aula hipertrofia e reifica esse material como balizador de todo o processo educacional. Segundo os autores, é preciso considerar as vivências que saem pelos poros da sociedade, a cultura produzida pelos movimentos sociais e pelos diferentes meios de comunicação (filmes históricos, documentários, programas de televisão, novelas, peças teatrais, museus, guias, práticas e discursos das diferentes religiões, famílias e concepções políticas). Essa perspectiva, do cruzamento de fronteiras e de conceitos históricos (ou relacionados ao ensino de História) construídos em rede, em muitos espaços e por múltiplos sujeitos, é o fazer e também objeto da análise da história pública.

No entanto, é preciso reafirmar que ela não está restrita à ampliação da transmissão e de suas audiências, nem aos usos de tecnologias que facilitam o acesso às informações. Esse é um aspecto fundamental, que dialoga com a primeira dimensão de história pública aqui citada. Pretende-se avançar, entendendo que mais do que comunicar, é preciso promover a reflexão sobre os usos do passado no presente. Falo de um posicionamento que dialoga com o saber historicamente acumulado, que chega à escola pelos mais diferentes meios e que precisa ser racionalizado, ao mesmo tempo que deve tocar e sensibilizar.

Segundo a definição de Penna e Silva (2016), a história pública trata de questões socialmente vivas. Aborda a dimensão do tempo presente, que procura refletir sobre as rupturas e permanências que fazem sentido para nossos 
alunos; que estão postas em discussão nas redes em que eles estão envolvidos e que exigem, muitas vezes, confronto e crítica. Há que se preocupar com explicações relativas ao passado em redes com excessos de informes que podem confundir em vez de esclarecer.

É o caso dos depoimentos orais disponibilizados na internet pela Comissão Nacional da Verdade (2012-2014) e que podem ser facilmente acessados. A ideia de garantir o livre circuito das narrativas de pessoas agredidas nos órgãos de repressão e de agentes do Estado, confrontados no regime autoritário, é fundamental para se colocar em jogo memórias divergentes, contribuindo para que um público cada vez maior possa conhecer, reconhecer e se posicionar diante do passado. Não se questiona a importância desse viés relativo ao direito da memória, próprio da chamada justiça de transição. $\mathrm{O}$ problema desse tipo de concepção - volto a afirmar - é a crença até mesmo ingênua de que a divulgação dos testemunhos baste para se condenar um passado repleto de violências e que seja usado para o "Nunca Mais".

Assistimos no país, no tempo presente, a uma diversidade de posturas intolerantes e banalizadoras em relação à ditadura e à tortura, fazendo usos dos relatos dos agressores justamente para justificá-las. Nas redes sociais e em manifestações políticas recentes, nas ruas, indivíduos e grupos procuram defender a sua "necessidade" como forma de "acessar informações de crimes" ou "combater terroristas". Para isso, muitas vezes, discursos como o do coronel Brilhante Ustra são citados para embasar a defesa da ditadura e da intervenção militar. É preciso mediação, e nesse sentido a escola pode atuar como oportunidade de ponderações sobre as memórias, a história e seu "consumo virtual" sem reflexão mais profunda. Não considero, aqui, que o professor de História seja o responsável pelas leituras e interpretações de concepções divergentes, que deva "corrigi-las" ou reafirmá-las. Entendo que ele, no entanto, pode contribuir - e muito - para que os estudantes sejam capazes de não cair em simplismos explicativos e para que possam ser tocados pelos passados vivos que compõem as memórias dos narradores sobre a ditadura. Considerar os depoimentos em primeira pessoa, em sala de aula, é pensar coletivamente sobre o papel do testemunho, entendido de duas formas - como daquele que vivenciou diretamente a experiência e daquele que viu acontecer (Seligmann-Silva, 2010, p. 5). Diante dos excessos e distorções, é fundamental combater a banalização da violência e considerar "a potencialidade das narrativas midiáticas na 
produção/divulgação de representações acerca do passado - portanto, formação de consciência histórica - e na fundamentação de cultura histórica na contemporaneidade" (Wanderley, 2016, p. 209).

Os vídeos disponibilizados pela Comissão Nacional da Verdade (CNV) e analisados em sala podem representar um exercício importante do ouvir e do dizer, da troca de ideias, de leituras e percepções sobre o que foi narrado por pessoas que sofreram a agressão e por agentes que a praticaram. Admitir as múltiplas perspectivas não é negar a verdade histórica nem significa igualar todas as versões como opiniões. É justamente isso que se quer rebater. $\mathrm{O}$ aprendizado histórico deve ser entendido como capaz de promover um conjunto de competências que permita aos alunos distinguir com clareza os eventos do passado, entendidos a partir de questões do presente, reconhecendo sujeitos em seus lugares de fala e os mecanismos de circulação de suas mensagens, estabelecendo conexões de significados e de sentidos com a realidade.

Buscando considerar procedimentos em aula para análise, sugiro que façamos um breve histórico sobre a chamada justiça de transição no Brasil, com a criação da CNV, e um exercício pensando possibilidades de se trabalhar com os depoimentos que estão disponíveis no site da Comissão, assim como em muitos links no YouTube, sob a perspectiva da história pública que "abraça a controvérsia".

\section{O TESTEMUNHO PÚBliCo CONTRA O SILÊNCIO DA ANISTIA POLÍTICA}

No ano de 1979, quando a ditadura brasileira estava em crise, os militares trataram de se defender diante das acusações de setores da sociedade civil sobre graves violações de direitos humanos cometidas durante o regime autoritário (1964-1985). Em meio a debates sobre as condições de presos e exilados políticos, e dos possíveis responsáveis pelos crimes de assassinato e "desaparecimento" de pessoas, nos anos 1960 e 1970, a criação da Lei 6683/79 declarava a Anistia, por parte do Estado, a todos que haviam cometido crimes políticos, excetuando-se dos benefícios os que haviam sido condenados pela prática de crimes de terrorismo, assalto, sequestro e atentado pessoal.

Com a Anistia, decretava-se o silêncio. Para Paul Ricoeur (2007), era a “mágica de fazer esquecer" em nome da chamada reconciliação. Ao promover o esquecimento de nomes, lugares e eventos conflituosos da ditadura, 
intentava-se fazer desaparecer o dolo e os responsáveis por ele. Mais ainda, constituiu-se uma confusão perversa do sentido de "crime político", considerando-se que torturadores fossem "perdoados" enquanto grupos opositores fossem considerados "terroristas". Outro equívoco intencional, por parte do Estado militar, foi tornar anistia e perdão sinônimos. A ponderação sobre esses conceitos não é o tema deste artigo, mas pode surgir em sala, demonstrando como o primeiro pode impedir o segundo.

Para o momento, importa compreender que os processos de silenciamento nunca são silenciosos, de fato. Muitas memórias machucadas continuam a existir. Essas memórias subterrâneas (Pollak, 1989) ou esses passados vivos que se alimentam nos espaços mais íntimos e cotidianos estão prontos para vir à tona a qualquer momento. A anistia não é capaz de calar, porque não é capaz de fazer esquecer a violação e seus efeitos, não apenas para quem foi por ela vitimado diretamente, mas pela sociedade atingida de inúmeras formas simbólicas. O que vimos nos últimos anos foi a força com que passaram a ocupar espaços públicos as narrativas daqueles que foram perseguidos ou dos que com eles viveram o sofrimento da tortura. Isso ocorreu nos museus e memoriais, nos livros, nas mídias virtuais e na própria sala de aula, aliando memórias e história.

Esse processo de rompimento de certo silêncio por meio da denúncia e do enfrentamento das memórias de violações aos direitos humanos e do reconhecimento das vítimas vem ganhando cada vez maior proporção com a valorização dos relatos em primeira pessoa. O testemunho sobre o passado traumático coloca em xeque toda tentativa de anistiar o perpetrador, antes mesmo de se criar uma comunidade de narradores e de ouvintes, capazes de acessar e de produzir um conhecimento sobre o passado autoritário, atribuindo nomes e responsabilidades. Já não é possível anistiar ou perdoar o criminoso sem saber seu crime e seu nome. Trata-se, cada vez mais, da busca pela superação da impunidade dos delitos cometidos, reforçando um caminho conhecido como justiça de transição. Nesse caminho, é preciso fortalecer quatro dimensões fundamentais: a garantia do direito à verdade e à construção da memória; a responsabilização e a reparação dos crimes cometidos; a regularização da justiça e o restabelecimento da verdade perante a Lei; a reforma das instituições perpetradoras de violações contra os direitos humanos (Abrão; Torelly, 2014). 
A possibilidade de enfrentar o trauma coletivamente, pelo conhecimento do passado e pelo reconhecimento da dor, atribuindo responsabilidades e pensando formas de reparação, pode significar o poder restaurador da "cura" de feridas que ainda não fecharam, e que anistia alguma pode amenizar se não passar pelo debate público, de forma a reconstruir as relações de confiança entre a população civil e o Estado. O processo de constituição e atuação da Comissão Nacional da Verdade (CNV), entre 2012 e 2014, inseriu o Brasil numa conjuntura mundial de disputas por memórias que se iniciaram e se ampliaram em muitos países, como África do Sul, Espanha, Argentina e Chile, entre tantos outros, resultados de movimentos sociais que se pronunciaram favoráveis à confrontação de memórias e à investigação dos regimes autoritários pelos quais haviam passado. Ocorreu o que Michael Pollak (1989) chamou de uma irrupção de "memórias subterrâneas" que, em momentos de enfraquecimento de uma memória hegemônica, de mudanças políticas e culturais, tomam o espaço público a fim de refletir sobre o passado que não passou, sobre a anistia que não perdoa, renovados pelos problemas e pelas questões do presente.

\section{AS NARRATIVAS DOS PERPETRADORES: POR QUE OUVI-LAS?}

A Comissão Nacional da Verdade, constituída pela presidenta Dilma Rousseff em 2012, contou com a participação voluntária daqueles interessados em testemunhar sobre as inúmeras violações sofridas no cárcere e em lugares clandestinos, durante a ditadura militar (1964-1985), e também com convocações nas audiências públicas. Deve-se deixar claro que se tratava de uma comissão organizada pelo Estado e não pela sociedade civil, mas que procurou interagir com setores políticos favoráveis ao enfrentamento de memórias. Inúmeras comissões estaduais e municipais também foram formadas, dialogando e alimentando informações. Centenas de pesquisadores, dentre eles muitos historiadores, atuaram na recolha de documentos privados e oficiais, assim como na escuta de pessoas que se dispuseram a romper silêncios e compartilhar suas dores (Comissão..., 2014).

Embora tenha exercido a finalidade de investigação em todo o país, não se pode afirmar que as atividades da CNV tenham ganhado uma dimensão pública, o suficiente para envolver a população em torno dos depoimentos e 
debates. Elas provocaram certo ruído que incomodou aqueles que foram responsabilizados pelas violências cometidas. Chamados a entregar documentos e a também narrarem sua participação nos eventos traumáticos, muitos membros das Forças Armadas e da repressão resistiram e silenciaram, num acordo velado entre oficiais mandantes e executores. Ao se colocarem em posição de confronto com a memória dos atingidos pela ditadura, os testemunhos de perpetradores seguiram uma tendência semelhante em acusar todos aqueles que se voltaram à defesa da memória traumática, nomeando-os como "esquerda revanchista" e questionando a validade da Comissão.

Desde o final da ditadura, na década de 1980, alguns agentes da repressão, como Marco Pollo Giordani e o coronel reformado Carlos Alberto Brilhante Ustra, ambos agentes do Destacamento de Operações de Informação - Centro de Operações de Defesa Interna (DOI-Codi), haviam procurado responder a denúncias de opositores políticos, por meio de publicações como Brasil: Sempre (1986) e A verdade sufocada (1987). Sobre essa postura, Caroline Bauer (2018, p. 197) afirma que em suas obras e manifestações, esses sujeitos organizaram não apenas discursos negacionistas sobre o passado, mas também dois tipos de revisionismos: o crítico e o apologético. Esses aspectos podem ser vistos claramente nos relatos apresentados por eles à Comissão da Verdade e que nos interessam como material a ser pensado em sala de aula, necessitando serem compreendidos no debate público, na inter-relação entre seus autores, seus locais de produção e de difusão virtual, no sentido de justificar as ações do passado e reafirmar seu posicionamento político no presente:

As representações do passado elaboradas e difundidas por esses sujeitos vinculados ao período ditatorial possuem coesão e estabilidade, configurando uma 'comunidade de memórias'. Nessa comunidade, a pós-verdade é uma marca, pois os fatos possuem menos importância que os apelos à emoção, às memórias herdadas e às experiências pessoais. Caracterizados por uma retórica marcada por distorções e idealismos, esses discursos não necessariamente negam ou revisam a ditadura, mas procuram justificar e legitimar suas práticas, principalmente pela crença na efetividade do terrorismo de Estado, no caso de atores civis e militares implicados na violação de direitos humanos, ainda, pela busca de absolvição ou desresponsabilização por ações criminosas... (Bauer, 2018, p. 201) 
No sentido inverso ao da chamada justiça de transição, eles reafirmam uma cultura autoritária e de impunidade, na defesa da Lei da Anistia e de uma reconciliação sem acusação e sem responsabilização. Esse tipo de posicionamento desmoraliza os agredidos e coloca-os em descrédito, ao mesmo tempo que nega a veracidade de seus relatos ou procura equivaler as violências cometidas pelo Estado e pelos grupos de oposição. Essa posição reabilitadora da ditadura pode ser observada na conjuntura recente do país, em que discursos cada vez mais intolerantes, no senso comum, pedem pela intervenção militar ou apoiam figuras políticas autoritárias: "Ao demandarem o retorno dos militares ou uma 'intervenção militar constitucional', muitas pessoas sabem exatamente o que estão pedindo, e percebe-se que o discurso apologético à ditadura se legitima na tradição e cultura autoritárias brasileiras, que levam à naturalização de atos de autoritarismo e violência” (Bauer, 2018, p. 202).

Os testemunhos daqueles que sofreram e sobreviveram aos abusos podem representar o acesso à verdade sobre aquilo que foi ocultado e desprezado pela ignorância de alguns ou pela intencionalidade consciente de outros. Na tentativa de se criar uma comunidade de narradores e de ouvintes, a Comissão Nacional da Verdade se dispôs a compartilhar publicamente, em forma do relatório final entregue em dezembro de 2014 ou na organização do site http:// memoriasdaditadura.org.br/comissao-nacional-da-verdade/index.html, todas as tomadas de depoimento, assim como os resultados de trabalhos desenvolvidos pelos pesquisadores. Além disso, é possível assistir no YouTube e em outras redes virtuais a vários vídeos com trechos dos relatos de vítimas e de seus algozes.

Essa dimensão coletiva e virtual dos discursos conflitantes, no entanto, não é suficiente para cumprir o que a história pública se dispõe: o compartilhamento, o debate e a construção de uma consciência histórica sobre nosso passado doloroso. Comunicação sem reflexão não se constitui em coletividade e no necessário combate a uma cultura autoritária e banalizadora da violação dos direitos humanos. Deve-se considerar todo o trabalho das equipes envolvidas com a Comissão da Verdade e a disponibilização das ações e discursos nas redes como fundamentais para que se reconheça que o conhecimento histórico pode e deve ser difundido também fora da Academia e que os documentos ali encontrados e/ou produzidos podem servir como fontes para a ciência e também para o ensino. Mas o livre acesso a eles não basta. Primeiro, porque 
são frutos de discordâncias, de disputas por memórias, que precisam ser submetidos à análise; segundo, porque o público receptor não é mera audiência, mas precisa ser estimulado a desenvolver a reflexão sobre seu passado.

Ao pensar sobre a forma como a informação tem sido facilmente acessada pelas novas tecnologias, Mary Marshall Clark (2009) chamou a atenção para o fato de que os excessos com que imagens e narrativas sobre a violência entram em nossas casas têm dificultado a sensibilização sobre as tragédias humanas, de modo a evitar novas formas de violação:

O perigo é que a velocidade e a abrangência da mídia ameaçam esmagar e substituir a memória pessoal, contribuindo para uma nova e insidiosa indiferença, que não pode ser explicada pela falta de conhecimento. Como consequência, nos tornamos espectadores da História, aptos a racionalizar a indiferença em nós mesmos através da rendição a um clima de alienação da nossa cultura. (Clark, 2009, p. 151)

Nesse sentido, os recursos comunicacionais permitem a ampliação da divulgação de versões sobre os eventos, mas não garantem a construção de uma história pública democrática, entendendo-os também como construção discursiva. É preciso mediação histórica, compreendida como a submissão da quantidade à reflexão qualitativa, aos cruzamentos de discursos com os contextos de sua produção, com outros documentos e com a análise da própria ideia de testemunho.

Pode-se falar de um testemunho do perpetrador? Em que a análise de seus depoimentos negacionistas ou revisionistas pode contribuir para o debate sobre a dignidade afetada, sobre o passado traumático e sobre os direitos humanos? Qual é a importância de se trabalhar com os posicionamentos públicos de perpetradores? Esses questionamentos devem ser desenvolvidos em sala de aula.

\section{A HISTÓRIA PÚBLICA, AS MíDIAS E O ENSINO DE HISTÓRIA}

Entendo a história pública como todo o processo de comunicação que culmina com a ponderação coletiva e com a mediação histórica. No caso do tema deste artigo, é toda reflexão que não banalize a violação do direito e não iguale "senso comum" e conhecimento histórico, a partir da "livre interpretação" dos 
testemunhos. É evidente que o chamado senso comum tenha sua contribuição, nascendo das experiências vividas de formas diferenciadas por segmentos diversos da sociedade. Não se está afirmando, aqui, que os indivíduos não tenham capacidade para organizar informações e processá-las. Pelo contrário, sabe-se que a produção e a recepção individual ou coletiva estão atravessadas justamente por aspectos das múltiplas vivências, o que colabora para a constituição de representações sobre o passado, as quais compõem o imaginário social.

Entretanto, é preciso considerar que sem o conhecimento histórico, acumulado e sistematizado sobre os processos humanos, corre-se o risco de simplificações históricas, preconceitos e indiferenças. Por isso, quando assistimos a uma proliferação de livros ou de vídeos que transformam nossa história em entretenimento, sem cuidar dos procedimentos de distanciamento analítico, estamos em terreno perigoso e movediço. Da mesma forma, as inúmeras imagens e palavras disponibilizadas pela Comissão da Verdade por meios virtuais, sem a devida moderação do processo histórico, permitem inúmeras apropriações, variados usos do passado, que podem promover efeito contrário ao que se pretendia: a banalização da dor, o desrespeito à vítima, os recortes negacionistas, o descrédito da própria democracia.

Desejo, então, reafirmar a enorme - e não exclusiva - importância que o ensino ganha quanto ao redimensionamento da publicização, transformando o conhecimento coletivo em história pública, de fato. É preciso reconhecer o papel fundamental do docente, em diálogo com seus alunos e com a comunidade escolar, nesse processo de trazer para dentro da sala de aula a informação difundida, com a finalidade de submetê-la à discussão, assim como reinventar novas formas de publicizá-la, de maneira a constituir a consciência histórica, esta última entendida como "a suma das operações mentais com as quais os homens interpretam sua experiência da evolução temporal de seu mundo e de si mesmos, de forma tal que possam orientar, intencionalmente, sua vida prática no tempo" (Rüsen, 2012, p. 57). A interpretação e a consciência não devem ser confundidas com a liberdade imaginativa de se explicar os acontecimentos a partir somente do lugar das experiências. Elas precisam ser levadas em conta, mas é necessário cruzá-las com uma herança epistêmica que embase o entendimento histórico. Daí a importância do educador que trabalha com a perspectiva da história pública como diagnóstico e reflexão sobre a divulgação. 
Pensar com os alunos sobre os usos e sentidos do passado para agredidos e agentes da repressão, que se confrontaram no espaço da Comissão da Verdade, significa pressupor que aqueles que narram são e não mais são aquelas pessoas do fato narrado. Há que tratar das memórias dos eventos em disputa e de suas relações com a história, levando em conta como as pessoas afetadas foram transformadas pelas trajetórias de vida, pelos projetos de futuro e, ainda, pelas próprias expectativas criadas pela publicização de suas narrativas. Compreender que elas narram para si, para a comunidade à qual pertencem - seus pares -, para o ouvinte imediato e para múltiplas gerações que existem e que estão por vir. Mais do que isso, o professor pode ponderar com os discentes o sentido da publicização dos depoimentos, os efeitos da ampliação do acesso e da audiência provocada pelos meios de comunicação, no caso a virtualidade da internet, orientando o olhar interpretativo sobre a ditadura.

Proponho que essa dinâmica não passe apenas pelos testemunhos das pessoas vitimadas pela violência: mulheres, homens, das mais diferentes profissões, posicionamentos políticos, etnias, religiões, sexualidades. Há que se levar em conta as versões, os silenciamentos, os negacionismos também apresentados por aqueles que defendem uma imagem positiva da ditadura, legitimando-a. Em primeiro lugar, para questionar com os estudantes se o que aqueles sujeitos fazem é testemunhar (o agressor é confiável sobre a violência?); se negam, por que o fazem? Se confessam, qual é o valor político e ético? Diante das câmeras e da potencialidade da internet, o que lhes interessa dizer sobre a violação, e por quê?

Os livros didáticos, materiais tradicionalmente usados em sala de aula, não têm sido suficientes para evidenciar essas disputas por memórias e estimular em nossos estudantes a percepção sobre as tensões que atravessam e que também escapam da escrita da história. Em vez de ignorarmos, como professores e cidadãos muitas vezes incomodados, as versões apresentadas pelos agentes da repressão, defendo a ideia de que podemos usar os suportes públicos para conhecê-los, estudá-los, interpretá-los e desconstruir seus discursos com as novas gerações que não viveram a ditadura. Compreender o sentido dos negacionismos e revisionismos e também a contribuição das confissões, uma vez que elas também ocorreram.

A Comissão Nacional da Verdade disponibilizou centenas de depoimentos. Dentre eles, quero dar destaque aos relatos de Dulce Pandolfi, Lúcia 
Duprat e Márcia Basseto, militantes políticas, por sua gravidade e por revelarem as questões de gênero que envolveram a repressão e a tortura no período. O docente poderá colocar em confronto informações, mas poderá explorar, em especial, o valor da memória e do testemunho no contexto de justiça de transição com seus alunos. Além das declarações das vítimas - que são muitas e podem ser selecionadas no site da CNV -, quero enfatizar e sugerir três outras narrativas, de perpetradores, como as do coronel Carlos Alberto Ustra, acusado por inúmeros presos como torturador no DOI-Codi; o coronel Paulo Malhães, que atuou no Centro de Informações do Exército (CIE), e o delegado Cláudio Guerra. O primeiro assumiu a postura negacionista quanto aos crimes cometidos e aos mortos sob tortura no DOI-Codi e acusou os depoentes de mentirem e de serem revanchistas; o segundo procurou justificar e legitimar as ações contra opositores a quem chamou, como Ustra, de terroristas, defendendo a ideia de que o país foi salvo dos comunistas. O último, entretanto, também autor de um livro Notícias de uma guerra suja (Topbooks, 2012), dizendo-se convertido religiosamente, pronunciou-se arrependido, confessando diferentes crimes e contribuindo para localizar "desaparecidos", indicar lugares e nomear os respectivos assassinos.

Todavia, qual seria a importância de se ver e analisar, além das declarações das vítimas, as memórias também de seus algozes? Primeiro, procurar mediar com os alunos a importância e o sentido da divulgação dessas informações e do quanto elas produzem conhecimento e também promovem uma formação histórica, que deixa ao espectador a responsabilidade também por pensar sobre o passado e entender-se no presente. Segundo, alertar para a necessidade de que a história comunicada (publicizada, divulgada por diferentes meios midiáticos e pelo ensino escolar de história) se converta em história pública, com o compromisso ético da divulgação e de seus efeitos sobre o entendimento histórico, enfatizando a qualidade que se ganha com o cruzamento de concepções teóricas acumuladas pelo aprendizado mais sistematizado. A história pública leva em conta as muitas outras formas de se difundir o conhecimento, mas não abre mão da ciência histórica. ${ }^{1}$

Por se tratar de longas audiências, caberia ao docente ou aos próprios alunos, orientados e divididos em grupos, selecionar trechos que permitissem observar representações sobre os sujeitos - agentes do Estado e opositores -, perceber tensões e contradições, performances narrativas, confrontos de 
memórias. Os depoimentos de agentes da repressão, assim como os das vítimas, contribuem para esclarecer os processos de violações, de tortura, assassinato e desaparecimento de pessoas. Suas informações podem confirmar os testemunhos das vítimas e colaborar para que o direito à verdade seja garantido, esclarecendo fatos ocultados e distorcidos pela memória constituída pela anistia. Isso não significa afirmar, em nenhuma hipótese, que seus discursos sejam mais verdadeiros e mais passíveis de credibilidade do que os de qualquer vítima. No entanto, quando se dispõem a admitir o que fizeram - como Paulo Malhães e Claudio Guerra em suas confissões à Comissão -, é possível confirmar as revelações daqueles que sobreviveram, colaborando para superar dúvidas e descréditos que pesam sobre eles, para nomear responsáveis e para construir uma consciência histórica pela qual a sociedade possa encarar e aceitar a veracidade dos terríveis fatos que a atingiram no passado e que continuam a afetá-la no presente.

Longe de promover, entre os alunos, uma crença na palavra e na performance dos perpetradores como "senhores da verdade", ou pelo contrário, o descrédito e o desprezo total por seus relatos como algozes, interpretando-os como mentiras deliberadas e falseamentos, o que se propõe é que possam refletir sobre o valor de seus ditos e versões, na comparação com seus opositores políticos, com seus pares e por si. Nesse sentido, perguntando quem eram eles, suas relações políticas e sociais no regime autoritário e seu posicionamento hoje, pode-se esclarecer muito sobre os procedimentos pessoais ou institucionais para exercerem a violência naquele período; as representações com que lidavam e lidam hoje sobre seus adversários políticos e, ainda hoje, as condições que os levam a negar, a rever ou a confessar os crimes cometidos, na arena pública. Suas narrativas podem ser usadas até mesmo para desconstruir outras, de agentes que negam os eventos, como Ustra, fazendo muitos silêncios e interditos também dizerem.

O objetivo, enfim, consiste em problematizar em aula os processos de narrativização do passado, levados a efeito pelas explanações de vítimas e de agressores que estão disponíveis na internet, por meio de vários links difundidos não apenas, mas principalmente, pela Comissão Nacional da Verdade, procurando contribuir para tornar mais árida, mas também mais múltipla, a memória sobre o passado, sua difusão e seus usos políticos e sociais. Importam os conteúdos relativos aos eventos em si - os fatos, nomes ou 
atividades, que podem ser confrontados -, mas também as estratégias de autorrepresentação e de autojustificação; os modos narrativos de naturalização da história de violência com que os perpetradores lembram, dispostos a convencer o público que esteve presente nas audiências, mas também aquele que acessa as mídias virtuais, como um produto de convencimento.

\section{CAMINHOS PARA TRANSFORMAR A PUBLICIZAÇÃO DO EVENTO EM HISTÓRIA PÚBLICA NA SALA DE AULA}

Edson Teles (2015, p. 49) afirmou que "o sofrimento pelo qual passamos em nossa existência somente pode ser absorvido e transformado em experiências se pudermos conceder-lhe publicidade, ou seja, partilharmos do vivido como uma existência pública". Para ter existência pública, reafirmo, é necessário que haja discussão, empatia, cruzamento de experiências e saberes, organização de conceitos.

O professor pode ser o promotor, o mediador desse processo de criação de uma comunidade de ouvintes para a comunidade de narradores públicos, orientando sobre a apropriação dos testemunhos disponíveis no site da Comissão Nacional da Verdade. A forma como conduzir as leituras e as considerações coletivas em sala de aula dará suporte em outras situações nas quais se exija do aluno a compreensão de outras narrativas e temporalidades, acionando o conhecimento histórico. Proponho, então, que um dos primeiros procedimentos em sala de aula, voltado à escuta sensível e coletiva dos relatos de vítimas ou de perpetradores, seja a discussão em torno da história e dos significados da existência das comissões da verdade pelo mundo e sua especificidade no caso brasileiro. Lembrar com os alunos sobre os sentidos de sua criação e de sua nomeação como "comissão da verdade". Como tal, quem dela pode participar e o que explica a necessidade de uma comissão para descobrir a "verdade", ou qual verdade? A sua constituição revelaria, a partir do contexto de criação e dos sujeitos envolvidos - a favor ou contrários a ela - as tensões entre as memórias e os esquecimentos expostos na arena coletiva, questão imprescindível para se começar a pensar a importância da história pública como divulgação e como reflexão.

A Comissão Nacional da Verdade, que iniciou os trabalhos em 2012, trabalhou com 13 grupos de pesquisadores, dentre eles muitos historiadores, 
divididos nos seguintes temas: ditadura e gênero; guerrilha do Araguaia; contextualização, fundamentos e razões do golpe civil-militar de 1964; ditadura e sistema de justiça; repressão aos trabalhadores e ao movimento sindical; estrutura de repressão; mortos e desaparecidos políticos; graves violações de direitos humanos no campo ou contra indígenas; Operação Condor; o Estado ditatorial-militar; papel das Igrejas durante a ditadura; perseguição a militares; violações de direitos humanos de brasileiros no exterior e de estrangeiros no Brasil (Comissão..., 2014). Cada um dos arquivos pode ser acessado por qualquer pessoa que esteja interessada em conhecer as informações ali publicadas.

É possível organizar os alunos para que se ocupem em ouvir - ou ler - os inúmeros relatos de grupos como mulheres, camponeses, indígenas, intelectuais, religiosos ou homossexuais que contribuíram para a construção de uma consciência coletiva e pública, que só pode se realizar assim se contribuirmos para a construção de uma comunidade de ouvintes. E nossos alunos podem ser, mais do que essa comunidade de ouvintes, também mediadores e ampliadores dessas vozes, em sua família, em seus bairros, em suas redes de comunicação. As aulas podem contribuir para compreenderem que, mesmo pertencendo a gerações que não viveram a ditadura, possam sentir-se parte de um longo processo que os atinge pela humanidade, pelo sentido de coletividade, pelo direito à verdade, à reparação e à justiça, compartilhando uma história aberta, do passado vivo, do tempo presente, na qual docentes e alunos estão inseridos, vivendo suas permanências e efeitos.

O amplo acesso poderia já ser motivo de discussão com os alunos quanto ao seu valor político, social e educacional, além do fato de eles poderem conectar as páginas e trazerem para a sala de aula uma série de questões em torno do conteúdo ali disponível sobre o regime autoritário. O debate em torno da Lei de Acesso à Informação (Lei no $12.527 / 2011$ ) que fortaleceu um princípio democrático, próprio da justiça de transição, que é o do direito à memória e à verdade histórica, também poderia incrementar a reflexão sobre o passado vivo e socializado.

Em sala de aula, o educador deve atuar sempre como um provocador, um acionador de questionamentos e mediador de saberes. Diante de tamanha quantidade de informações e de testemunhos disponibilizados publicamente, ele pode estimular, junto aos meninos e meninas, rodas de conversa que levem a cogitar: diante de tamanho registro e da facilidade de acesso aos grupos de 
trabalho e às tomadas de depoimentos, por que vivemos um processo em que ainda se nega o passado ou se defende a banalização do horror?

Ponderar com eles como se deu o processo de constituição, condução e publicização dos resultados da Comissão; como os dados públicos e as declarações orais foram colhidos, como estão dispostos na internet, quem os acessa e em que condições, são procedimentos importantes, além de outros questionamentos: Que usos são feitos dessas narrativas e que espaços alcançam, além do privado? Como a escola lida com eles, se os utiliza para esclarecer ou para pensar as memórias, a democracia? Quem são as pessoas que narram hoje, longe daquilo que um dia exerceram nas relações políticas, onde estavam, onde estão hoje? Como combater os negacionismos no senso comum?

Como proposto anteriormente, uma pesquisa e a seleção de trechos narrativos - ou exposições inteiras, dependendo do tempo e da dinâmica que se propõe em aula - favorecem a reflexão sobre um ensino de história na perspectiva da história pública que coloca em evidência a perspectiva de quem foi machucado, mas também de quem torturou. Acessar esses discursos e imagens como documentos históricos e como manifestações orais é de uma riqueza imensa para compreender o conceito de testemunho e seu papel em países que vivem a justiça de transição, analisando as mensagens que querem publicizar ou negar, confrontando-as como disputas e analisando-as sob o referencial histórico. É importante que os discentes compreendam os espaços virtuais como lugares de disputas de memória em que cada grupo ou indivíduo que acessa pode "comprar" a ideia e passar adiante e, portanto, nada que ali se afirme é dotado de neutralidade.

Uma comparação possível para se entender a importância de uma história pública da ditadura seria analisar, com os alunos, o caso argentino, chileno ou sul-africano de recolhimento dos depoimentos e de tratamento dado a eles a partir de políticas públicas. Sem querer aprofundar, mas apenas para provocar ideias, o processo de constituição e atuação da Comissão da Verdade e Reparação (CPV) da África do Sul poderia ser conhecido também pelo registro público disponível em oito partes na internet. ${ }^{2}$ Criada pelo então presidente Nelson Mandela, ela investigou e colocou frente a frente vítimas e ofensores que se enfrentaram no regime de segregação racial (Apartheid). Tanto as audiências registradas no vídeo quanto a produção do filme em si poderiam ser objetos de análise. 
Entre os anos de 1996 e 1998, audiências foram realizadas em praças e ruas de cidades da África do Sul, com a participação direta da população. Brancos e negros se confrontaram sobre eventos de violação dos direitos humanos. Ali também se instituiu a possibilidade da anistia, mas com a condição - diferente do Brasil - de que a verdade fosse dita não apenas para ter a anistia, mas para o perdão dado pessoalmente pelos atingidos ou por seus familiares. Os depoimentos sul-africanos foram televisionados e difundidos pelas rádios, numa lição de história pública, comprometida com a construção coletiva do conhecimento e não apenas a sua divulgação a um público receptor. Para se ter ideia da extensão dessa Comissão, as declarações eram traduzidas simultaneamente para as mais diferentes línguas existentes nos espaços públicos. A participação e o acompanhamento direto das pessoas em todo o processo acionaram com maior vigor o sentimento de responsabilidade coletiva em relação ao passado, o que levou a políticas públicas de reparação do Estado, como o atendimento psicológico, por exemplo, aos sobreviventes e a exposição de nomes dos autores de violações que, se confessassem, teriam a possibilidade da anistia política e do perdão pessoal (Teles, 2015).

Essa breve menção à África do Sul é apenas uma possibilidade de procedimento didático quanto à compreensão: 1 . De concepções diferentes de história pública no trato de passados traumáticos e contextos de justiça de transição; 2. Da abordagem e análise das declarações de ofendidos e perpetradores em contextos diferentes de enfrentamento de memórias; 3 . Do valor das narrativas dos sujeitos praticantes de violência para esclarecimento de fatos e para o combate aos negacionismos, muitas vezes defendidos por seus pares. 4 . Da necessidade de se compreender que para cumprir seu papel como história pública, em seu sentido mais democrático, os fatos não podem ser limitados à comunicação ampla, mas precisam ser submetidos ao confronto público com a mediação da ciência histórica (sem contar, ainda, com a dimensão jurídica, neste caso).

Não compartilho da visão de que a realização dessa mediação deva ser feita por historiadores ou professores apenas, o que seria uma perspectiva muito simplista, mas defendo que o ambiente escolar tem muito poder no combate às fragilidades que os excessos de informações públicas podem representar à garantia dos direitos humanos. Quanto à temática da ditadura e dos testemunhos aqui proposta, a imaturidade e desconhecimento por parte dos alunos 
sobre seu passado histórico, os preconceitos elaborados involuntária ou intencionalmente por grupos sociais e políticos com os quais convivem, assim como a ausência de procedimentos capazes de habilitá-los para lidar com a publicização da história - muitas vezes convertida em simplificação e popularização rasa das relações humanas - exigem que o ensino de História se comprometa com uma história coletiva responsável, ética e sensível. Dessa forma, o docente envolvido com essa perspectiva deve se comprometer não a "salvar", mas a transformar a sala de aula em espaço público de reflexão.

A partir do acesso e da análise dos relatos, como podem os discentes atuar ativamente na constituição da história pública para fora da escola, envolvendo a comunidade e combatendo as banalizações em torno de violações e traumas? Que mecanismos podem ser pensados, elaborados, para que as discussões, uma vez mediadas pelas ponderações teóricas, sejam capazes de questionar concepções históricas midiatizadas como mero entretenimento, muitas vezes até de forma irresponsável, sobre o passado traumático? Eis um dos desafios propostos.

Para que o trabalho de pesquisa ganhe maior significado e possa ser divulgado além do espaço da sala de aula, o professor pode, ainda, propor aos alunos que criem formas de publicização e de envolvimento de pessoas, de forma a gerar uma comunidade de ouvintes em torno dos testemunhos da Comissão Nacional da Verdade. Dessa forma, eles poderiam compreender, na ação, o significado e a importância de se fazer história pública também como devolução.

\section{CONSIDERAÇÕES FINAIS}

Este artigo teve como finalidade apontar algumas reflexões e possibilidades de se transformar a difusão ampla de eventos e memórias em história pública, compreendendo esta última como um posicionamento que não se restringe à ampliação do acesso às informações sobre o passado, mas principalmente seus usos para a constituição de uma consciência histórica sobre o trauma coletivo.

Ao propor o trabalho com os depoimentos de violados e de violadores reunidos pela Comissão Nacional da Verdade e disponibilizados na internet, não se pretendeu exaltar os discursos negacionistas ou revisionistas 
apresentados por agentes da repressão. Pelo contrário, a ideia defendida é que o professor, como mediador importante, possa analisar com os alunos - sob a perspectiva histórica e a disputa por memórias - aquilo que está disponível a todos, com suas contribuições e seus perigos. Ouvir as versões de torturadores ou de seus mandantes não deve significar, nunca, acatar seu ponto de vista e reforçar simbolicamente a violência que atinge os sobreviventes. Pelo contrário, deve representar a oportunidade de, por meio da postura profissional e ética, colocá-las em confronto e desconstruí-las historicamente, combatendo discursos que desmerecem a dor e promovem a indiferença social.

É preciso que os alunos compreendam que os excessos de informação pública podem provocar banalizações e jogos de memórias perigosos à democracia, e que o livre acesso e a interpretação não são garantias democráticas em si. Como docentes comprometidos com a vida, é importante assumir essa mediação do público, com o público e para o público, fazendo compreender que as memórias dos testemunhos são filtradas pelo medo, pela mágoa, pela dor, pelo ressentimento, pela vergonha e também pelo poder, gerando tentativas de silêncios - mas que continuam a falar -, de generalizações, de excessos e também de denúncias graves que precisam ser ouvidas coletivamente para que se repare o dolo e se curem feridas sociais.

A controvérsia e a dimensão compartilhada da memória e da história devem ser ponderadas com nossos alunos. As pessoas envolvidas nos relatos orais sobre a ditadura nos vêm fornecendo documentos públicos para serem submetidos ao debate e à crítica. São registros relevantes da história do passado vivo ou do tempo presente, que comportam vozes múltiplas, muitas vezes discordantes porque partem de grupos que estão em constante conflito e que querem deixar suas marcas na história e para a posteridade. O ensino de História, nessa dimensão, pode e deve atuar possibilitando caminhos úteis para se lidar com os testemunhos, evitando reforçar explicações simplistas que o senso comum possa fazer sobre um passado complexo e doloroso para todos nós.

\section{REFERENNCIAS}

ABRÃO, Paulo; TORELLY, Marcelo D. Mutações do conceito de anistia na justiça de transição brasileira: a terceira fase da luta pela anistia In: ABRÃO, Paulo et al. 
Justiça de transição, direito à justiça, à memória e à verdade. João Pessoa: Ed. UFPB, 2014.

ANDRADE, Everardo P.; ANDRADE, Nívea. História Pública e educação: tecendo uma conversa, experimentando uma textura. In: MAUAD, Ana Maria; ALMEIDA, Juniele R.; SANTHIAGO, Ricardo. História Pública no Brasil: sentidos e itinerários. São Paulo: Letra e Voz, 2016. p. 175-184.

BAUER, Caroline S. Qual é o papel da história pública frente ao revisionismo histórico? In: MAUAD, Ana Maria; SANTHIAGO, Ricardo; TRINDADE, Viviane B. Que história pública queremos? What Public History do We Want? São Paulo: Letra e Voz, 2018. p. 195-205.

CLARK, Mary M. Vídeo-testemunhos sobre o holocausto, história oral, medicina narrativa: a luta contra a indiferença. Oralidades, São Paulo: USP, v. 6, p. 150-166, jan./ jun. 2009.

COMISSÃO Nacional da Verdade. Relatório. Brasília: CNV, 2014.

PENNA, Fernando de A.; SILVA, Renata Conceição A. As operações que tornam a história pública: a responsabilidade pelo mundo e o ensino de história. In: MAUAD, Ana Maria; ALMEIDA, Juniele R.; SANTHIAGO, Ricardo. História Pública no Brasil: sentidos e itinerários. São Paulo: Letra e Voz, 2016. p. 195-205.

POLLAK, Michael. Memória, esquecimento e silêncio. Estudos Históricos, Rio de Janeiro, v. 2, n. 3, p. 3-15, 1989.

RICOEUR, Paul. Memória, história e esquecimento. Campinas: Ed. Unicamp, 2007.

RÜSEN, Jörn. Aprendizagem histórica: fundamentos e paradigmas. Curitiba: W. A., 2012.

SANTHIAGO, Ricardo. História pública e autorreflexividade: da prescrição ao processo. Tempo e Argumento, Florianópolis: UFSC, v. 10, n. 23, p. 286-309, jan./mar. 2018.

SELIGMANN-SILVA, Márcio. O local do testemunho. Tempo e Argumento, Florianópolis: UFSC, v. 2, n. 1, p. 3-20, jan./jun. 2010.

TELES, Edson L. A. Democracia e estado de exceção: transição e memória política no Brasil e na África do Sul. São Paulo: Faap: Unifesp, 2015.

WANDERLEY, Sônia. Narrativas contemporâneas de história e didática da história escolar. In: MAUAD, Ana Maria; ALMEIDA, Juniele R.; SANTHIAGO, Ricardo. História Pública no Brasil: sentidos e itinerários. São Paulo: Letra e Voz, 2016. p. 207-217.

ZAHAVI, Gerald. Ensinando História Pública no século XXI. In: ALMEIDA, Juniele R.; ROVAI, Marta G. O. Introdução à História Pública. São Paulo: Letra e Voz, 2011. p. 53-63. 


\section{NOTAS}

${ }^{1}$ Mesmo que a história pública não seja campo exclusivo do historiador e que possa ser fruto de inúmeras negociações e demandas coletivas por reconhecimento; mesmo que possa ser produzida por comunidades de não historiadores, é preciso que a construção de uma "verdade histórica" seja preocupação constante; esta última entendida como própria de um presente que reinterpreta o passado e que projeta futuro, mas a partir de rastros e cuidados conceituais, evitando relativismos perigosos ou universalismos que não levam em conta temporalidades, sujeitos e lugares de produção. A ideia de uma história pública com o público (não audiência apenas, mas participante do processo de debate e mesmo de pesquisa), em que se possam realizar pontes entre Academia, escola e comunidades, em constante diálogo, pode ser um caminho de ponderações e mediações entre conhecimentos diferenciados e necessários.

${ }^{2}$ Disponível em: https://www.youtube.com/watch?v=V-TPzpvFo5U.

Artigo recebido em 10 de março de 2019. Aprovado em 11 de julho de 2019. 